MaPan : Jurnal Matematika dan Pembelajaran

p-ISSN: 2354-6883 ; e-ISSN: 2581-172X

Volume 7, No 2, December 2019 (194-210)

DOI: https://doi.org/10.24252/mapan.2019v7n2a3

\title{
PENGEMBANGAN PERANGKAT PEMBELAJARAN BERBASIS MEDIA APLIKASI GEOGEBRA PADA MATERI GEOMETRI UNTUK MENINGKATKAN HIGHER ORDER THINKING SKILLS SISWA
}

\author{
Shandy Agung1), Ma'rufi'2), Muhammad Ilyas ${ }^{3)}$ \\ 1,2,3Universitas Cokroaminoto Palopo \\ 1,2,3Jl. Latamacelling, Tompotika, Wara, Kota Palopo, Sulawesi Selatan \\ E-mail: shandy_agung@yahoo.com ${ }^{1}$, marufi@uncp.ac.id²), \\ muhammadilyas@uncp.ac.id ${ }^{3}$
}

Submitted: 23-10-2019, Revised: 20-11-2019, Accepted: 24-11-2019

\begin{abstract}
Abstrak:
Penelitian ini bertujuan mengembangkan perangkat pembelajaran berbasis media aplikasi geogebra pada materi geometri untuk meningkatkan HOTS siswa yang memenuhi kriteria kevalidan, kepraktisan, dan keefektifan. Subjek penelitian ini adalah siswa SMP Negeri 2 Luwu, sebanyak 30 siswa (kelas VIII A) pada uji lapangan awal dan 61 siswa (VIII E dan VIII F) pada uji lapangan utama. Prosedur pengembangan perangkat pembelajaran mengacu pada model pengembangan Borg and Gall yang telah dimodifikasi. Prosedur penelitian ini terdiri atas 7 langkah, yaitu: (1) penelitian awal dan pengumpulan informasi; (2) perencanaan; (3) mengembangkan format awal produk; (4) uji lapangan awal atau uji coba terbatas; (5) merevisi produk utama; (6) melakukan uji lapangan utama; (7) diseminasi dan implementasi. Instrumen yang digunakan dalam penelitian ini terdiri dari: (1) lembar validasi perangkat pembelajaran; (2) lembar observasi keterlaksanaan pembelajaran; (3) lembar observasi aktivitas siswa; (4) angket respon siswa; dan (5) tes hasil belajar siswa. Hasil penelitian ini adalah perangkat pembelajaran berbasis media aplikasi geogebra pada materi geometri untuk meningkatkan kemampuan HOTS siswa memenuhi kriteria kevalidan, kepraktisan, dan keefektifan.
\end{abstract}

Kata Kunci: Media, Geogebra, Higher Order Thinking Skills, Geometri

\section{DEVELOPING LEARNING TOOLS THROUGH MEDIA-BASED OF GEOGEBRA APPLICATIONS ON GEOMETRY MATERIAL TO IMPROVE THE HIGHER ORDER THINKING SKILLS OF THE STUDENTS}

\begin{abstract}
:
This study aimed to develop instructional media by applying geogebra on the topic of geometry to enhance students' higher order thinking skills. The subjects of the study were 30 seventh grade students of class A in SMP Negeri 2 Bua in the preliminary field testing and 61 eighth students of class $E$ and $F$ in the main field testing. The procedures of instructional media development consisted of seven steps which were (1) collecting information and preliminary study; (2) planning; (3) developing the preliminary form of the product; (4) testing the preliminary field; (5) revising main product; (6) testin main field; and (7) disseminating and implementing. Instruments used in the study were (1) validation sheet of instructional media;
\end{abstract}


(2) observational sheet of learning implementation; (3) observational sheet of students' activity; (4) questionnaire of students' response; and (5) test of students' learning outcome. Results showed that in improving students' higher order thinking skill on the topic of geometry, Geogebra as an instructional media fulfilled the criteria of validity, practicality, and effectivity.

Keywords: Media, Geogebra, Higher Order Thinking Skills, Geometry

How to Cite: Agung, S., Ma'rufi, \& Ilyas, M. (2019). Pengembangan perangkat pembelajaran berbasis media aplikasi geogebra pada materi geometri untuk meningkatkan higher order thinking skills siswa. MaPan : Jurnal Matematika dan Pembelajaran, 7(2), 194-210.

\section{PENDAHULUAN}

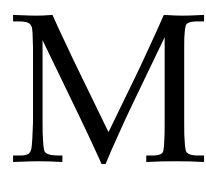

atematika merupakan mata pelajaran yang wajib dipelajari dari jenjang sekolah dasar agar peserta didik memiliki kemampuan dasar dalam kehidupan dan meningkatkan daya pikir. Menurut Uno dalam Ma'rufi, Pasandaran, \& Yogi (2018), matematika adalah suatu bidang ilmu yang berperan sebagai alat pikir, berkomunikasi, alat untuk memecahkan berbagai persoalan praktis, yang unsur-unsurnya logika dan intuisi, analisis dan konstruksi, generalitas dan individualitas, serta mempunyai cabang-cabang antara lain aritmetika, aljabar, geometri, dan analisis.

Geometri merupakan salah satu bidang dalam matematika yang mempelajari titik, garis, bidang dan ruang serta sifat-sifat, ukuran-ukuran, dan keterkaitan satu dengan yang lain (Nur'aini, Harahap, Badruzzaman, \& Darmawan, 2017). Geometri merupakan salah satu bidang kajian dalam materi matematika SMP yang memperoleh porsi lebih besar untuk dipelajari oleh siswa di sekolah dibandingkan dengan materi lain seperti aljabar, bilangan, statistika, dan peluang. Hal ini karena banyaknya konsep-konsep yang termuat di dalam geometri dan sifatnya yang abstrak, sehingga dalam mengajarkan geometri guru perlu merencanakannya dengan baik agar dapat dipahami oleh peserta didik.

Secara umum, geometri memiliki peluang yang besar dipahami oleh siswa dibandingkan materi lainnya karena ide-ide geometri telah dikenal siswa sebelum memasuki dunia sekolah (Ma'rufi, Pasandaran, \& Yogi, 2018). Namun kenyataannya, geometri masih dianggap salah satu materi yang paling sulit dipahami siswa. Hal ini terlihat dari hasil survey TIMSS dalam Azizah, Sujadi, \& Chrisnawati (2018) yang menyatakan rata-rata persentase 
jawaban benar siswa Indonesia pada bidang konten geometri sebesar $24 \%$ masih dibawah rata-rata persentase jawaban benar internasional sebesar 39\%.

Kondisi yang sama juga terjadi di SMP Negeri 2 Bua. Siswa masih kesulitan dalam mengerjakan soal-soal matematika utamanya geometri. Hal ini terlihat dari hasil Ujian Nasional Berbasis Komputer (UNBK) di SMP Negeri 2 Bua, nilai matematika siswa kelas IX masih tergolong rendah. Matematika merupakan mata pelajaran yang memperoleh nilai paling rendah di antara semua nilai mata pelajaran dan berada 7,46 poin di bawah rata-rata nilai sekolah. Dengan mengambil beberapa sampel nilai UNBK mata pelajaran matematika siswa kelas IX Tahun Pelajaran 2017/2018, terlihat banyak siswa mendapatkan nilai rendah pada aspek materi geometri dan pengukuran. Rendahnya hasil UNBK siswa pada mata pelajaran matematika khususnya geometri di SMP Negeri 2 disebabkan oleh beberapa faktor, selain konsepkonsep geometri yang sulit dipahami siswa, latihan yang diberikan guru pada pembelajaran hanya pada tingkat mengaplikasikan (kemampuan LOTS). Namun, soal-soal pada UNBK adalah soal-soal yang menuntut kemampuan berpikir tingkat tinggi (HOTS) siswa dalam menyelesaikannya.

High Order Thingking Skills (HOTS) merupakan kemampuan untuk menghubungkan, memanipulasi, dan mengubah pengetahuan serta pengalaman yang sudah dimiliki secara kritis dan kreatif dalam menentukan keputusan untuk menyelesaikan masalah pada situasi baru (Dinni, 2018). Menurut Suryapuspitarini, Wardono, \& Kartono (2018), soal dengan tipe HOTS adalah soal yang menuntut kemampuan berpikir tingkat tinggi dan melibatkan proses bernalar, sehingga dapat mengasah kemampuan berpikir kritis, logis, reflektif, metakognitif, dan kreatif. Berdasarkan hasil UNBK tersebut, terlihat bahwa kemampuan HOTS siswa di SMP Negeri 2 Bua pada pelajaran matematika khususnya geometri masih tergolong rendah, sehingga perlu upaya untuk meningkatkannya.

Upaya yang dapat dilakukan untuk meningkatkan kemampuan HOTS siswa pada pelajaran matematika khususnya geometri adalah memanfaatkan program komputer dalam pembelajaran. Pemanfaatan program-program komputer yang dapat dijadikan media dalam pembelajaran memungkinkan guru dapat melakukan proses pembelajaran dengan menarik. Dengan memanfaatkan program-program komputer membuat siswa lebih termotivasi dalam pembelajaran dan materi geometri yang bersifat abstrak akan lebih mudah dipahami oleh siswa. Clements dalam Abdussakir (2013) menyatakan bahwa penggunaan komputer dalam pembelajaran geometri perlu dilakukan. 
Dengan komputer, konsep geometri yang abstrak dan sulit akan menjadi lebih konkret dan jelas. Selain itu, penggunaan komputer dalam pembelajaran akan membuat siswa menjadi termotivasi dalam belajar.

Namun kenyataannya, walaupun terdapat komputer di SMP Negeri 2 Bua, pemanfaatannya dalam pembelajaran hanya diutamakan pada mata pelajaran teknologi informasi dan komunikasi (TIK) saja. Pemanfaatan komputer pada mata pelajaran matematika masih minim dilakukan. Hal ini dikarenakan perangkat pembelajaran yang digunakan guru tidak melibatkan penggunaan komputer dalam proses pembelajaran. Berdasarkan hal tersebut, perlu sebuah inovasi yang memungkinkan penggunaan komputer dalam pembelajaran matematika.

Terdapat berbagai macam program komputer yang bisa dimanfaatkan sebagai media dalam pembelajaran salah satunya adalah geogebra. Menurut Dewi dalam Sari, Farida, \& Syazali (2016), geogebra adalah sebuah software sistem geometri dinamis yang dapat mengkontruksikan titik, vektor, ruas garis, garis, irisan kerucut, dan fungsi kemudian mengubahnya secara dinamis. Dengan menggunakan program tersebut, maka objek-objek abstrak geometri dapat diwujudkan lebih konkret sehingga gambar-gambar titik garis dan bidang bisa ditampilkan lebih menarik dan jelas. Mahmudi (2011) mengatakan geogebra dapat dimanfaatkan sebagai media pembelajaran matematika khususnya geometri untuk mendemonstrasikan atau memvisualisasikan konsep-konsep geometri serta sebagai alat bantu untuk mengkonstruksi konsep-konsep geometri. Nur (2016) mengungkapkan ada tiga kegunaan geogebra dalam pembelajaran matematika, yaitu media pembelajaran matematika, alat bantu membuat bahan ajar matematika, dan alat bantu menyelesaikan soal matematika. Penggunaan aplikasi ini diharapkan dapat meningkatkan kemampuan berpikir tingkat siswa, khususnya di SMP Negeri 2 Bua.

\section{METODE PENELITIAN}

Jenis penelitian ini merupakan penelitian dan pengembangan (research and development). Model yang digunakan dalam pengembangan perangkat pembelajaran ini adalah model pengembangan Borg and Gall yang telah dimodifikasi menjadi 7 langkah pengembangan, yaitu: (1) melakukan penelitian awal dan pengumpulan informasi; (2) melakukan perencanaan (planning); (3) mengembangkan format awal produk; (4) melakukan uji coba terbatas; (5) merevisi produk utama; (6) melakukan uji lapangan utama; dan 
(7) melakukan diseminasi dan implementasi. Lokasi penelitian dilaksanakan di SMP Negeri 2 Bua Kabupaten Luwu. Waktu penelitian dilaksanakan pada semester genap tahun ajaran 2018/2019. Penelitian ini dilaksanakan di SMP Negeri 2 Bua pada siswa kelas VIII. Uji lapangan awal dilaksanakan pada kelas VIII A berjumlah 30 orang dan uji lapangan utama dilaksanakan di kelas VIII E dan VIII F yang berjumlah 61 orang.

Prosedur pengembangan yang dilakukan, yaitu tahap pertama melakukan penelitian awal dan pengumpulan informasi. Pengumpulan dan pengkajian literatur yang sesuai dilakukan dengan cara mengobservasi ke lapangan dan mengkaji hasil-hasil penelitian yang telah dilakukan oleh peneliti sebelumnya yang ada kaitannya dengan model yang dikembangkan. Tahap kedua, yaitu perencanaan (planning) seperti mengumpulkan buku-buku yang berkaitan dengan materi yang akan dikembangkan, menginstal aplikasi geogebra, membuat RPP yang sesuai dengan materi penelitian, buku bacaan siswa, LKPD, dan menyiapkan bahan-bahan sebagai evaluasi perangkat ini. Tahap ketiga yaitu mengembangkan format awal produk. Pengembangan bahan ajar berupa rencana pelaksanaan pembelajaran (RPP), lembar kerja peserta didik (LKPD), buku bacaan siswa, memilih dan mendownload media yang sesuai dengan materi, membuat evaluasi sebagai bahan tes, dan instrumen penilaian. Instrumen-instrumen kevalidan, kepraktisan, dan keefektifan direalisasikan pada tahap ini. Revisi dilakukan pada tahap ini berdasarkan saran dari validator. Validator yang digunakan adalah seseorang yang ahli dalam bidang ilmu matematika (ahli materi) dan seseorang yang ahli dalam bidang media pembelajaran (ahli teknologi). Tahap keempat, yaitu uji lapangan awal atau uji coba terbatas. Kegiatan yang dilaksanakan adalah mengujicobakan rancangan awal melalui pembelajaran di kelas VIII A yang berjumlah 30 orang SMP Negeri 2 Bua. Tahap kelima yaitu revisi produk utama. Hasil uji coba lapangan awal sebelumnya kemudian dilaksanakan revisi produk. Revisi ini dilakukan berdasarkan kesalahan pada uji lapangan awal. Tahap keenam, yakni uji lapangan utama. Kegiatan yang dilaksanakan adalah mengujicobakan rancangan awal melalui pembelajaran di kelas VIII E dan VIII F yang berjumlah 61 siswa SMP Negeri 2 Bua. Tahap ketujuh, yaitu diseminasi dan implementasi. Produk yang telah dibuat kemudian disebarluaskan kepada pihak yang terkait dan selanjutnya siap untuk diimplementasikan.

Instrumen yang dikembangkan pada penelitian ini, yaitu: (1) instrumen kevalidan yakni lembar validasi perangkat pembelajaran dan instrumen 
penelitian; (2) instrumen kepraktisan yakni lembar observasi keterlaksanaan pembelajaran dan lembar observasi aktivitas siswa; dan (3) instrumen keefektifan yakni angket respons siswa dan tes evaluasi kemampuan HOTS siswa.

Teknik pengumpulan data yang dilakukan adalah: (1) data kevalidan, angket validasi perangkat pembelajaran divalidasi oleh ahli atau dosen di pusat studi Universitas Cokroaminoto Palopo dengan cara memberikan tanda centang pada kolom skala penilaian. Adapun yang divalidasi adalah perangkat pembelajaran berbasis media aplikasi geogebra pada materi geometri yang dikembangkan; (2) data kepraktisan, keterlaksanaan pembelajaran dan aktivitas siswa diukur oleh observer atau pengamat. Pengamatan dilakukan oleh 2 orang guru di SMP Negeri 2 Bua untuk melihat bagaimana penggunaan perangkat saat proses belajar mengajar di kelas. Pengamat mencentang kolom skor yang telah disediakan; dan (3) data keefektifan, untuk mengukur kepraktisan perangkat pembelajaran, respons siswa terhadap perangkat diperlukan angket. Angket respons siswa diberikan kepada siswa setelah proses pembelajaran selesai, yakni pada pertemuan terakhir sebelum dilakukan tes. Tes yang digunakan untuk mengetahui kemampuan siswa dalam meningkatkan higher order thinking skills siswa Kelas VIII SMP Negeri 2 Bua adalah tes uraian. Tes awal ini dilakukan pada uji coba lapangan awal. Selain itu ada juga tes yang dilakukan pada uji coba utama dengan melakukan dua kali tes, yakni pretest dan posttest. Hasil pretest dan posttest ini kemudian dianalisis untuk mengetahui kemampuan siswa dalam meningkatkan higher order thinking skills.

Analisis data yang dilakukan adalah analisis data kevalidan perangkat pembelajaran, analisis data kepraktisan perangkat pembelajaran, dan analisis data keefektifan perangkat pembelajaran. Dalam menganalisis data kevalidan perangkat pembelajaran, dilakukan rekapitulasi hasil penilaian ahli dan praktisi ke dalam tabel, mencari rerata hasil penilaian ahli dan praktisi setiap kriteria, mencari rerata tiap aspek, mencari rerata total, menentukan kategori validitas setiap kriteria atau aspek atau keseluruhan aspek, kategori validasi setiap kriteria, setiap aspek, atau keseluruhan aspek. Kategori kevalidan yang dikutip dari Arsyad (2016), ditetapkan sebagai berikut:

$$
\begin{array}{ll}
3,5 \leq M \leq 4 & \text { Sangat valid } \\
2,5 \leq M<3,5 & \text { Valid } \\
1,5 \leq M<2,5 & \text { Cukup valid } \\
M<1,5 & \text { Tidak valid }
\end{array}
$$


Analisis data kepraktisan perangkat pembelajaran terdiri dari dua yaitu analisis data keterlaksanaan pembelajaran dan analisis data aktivitas siswa. Untuk menganalisis data keterlaksanaan pembelajaran, dilakukan rekapitulasi hasil penilaian ahli dan praktisi ke dalam tabel, mencari rerata setiap aspek pengamatan pada setiap pertemuan, mencari rerata tiap aspek pengamatan untuk $\mathrm{t}$ kali pertemuan, mencari rerata total, menentukan kategori validitas setiap kriteria atau aspek atau keseluruhan aspek, kategori keterlaksanaan setiap aspek, atau keseluruhan aspek. Kategori yang digunakan dikutip dari Arsyad (2016) sebagai berikut:

$$
\begin{array}{ll}
1,5 \leq M \leq 2 & \text { Terlaksana seluruhnya } \\
0,5 \leq M<1,5 & \text { Terlaksana sebagian } \\
0,0 \leq M<0,5 & \text { Tidak terlaksana }
\end{array}
$$

Dalam menganalisis data aktivitas siswa, pada hasil observasi setiap pertemuan, ditentukan nilai rata-rata dari setiap aspek aktivitas siswa (AS) dari pertemuan pertama sampai pertemuan terakhir dari materi yang diajarkan. Nilai AS ini selanjutnya dikonfirmasikan dengan interval penentuan kategori aktivitas siswa berdasarkan tabel berikut:

Tabel 1. Kategori Aktivitas Siswa

\begin{tabular}{cc}
\hline Interval & Kategori \\
\hline$\overline{\mathbf{A S}}<\mathbf{1 , 5}$ & TA (Tidak Aktif/Pasif) \\
$\mathbf{1 , 5} \leq \overline{\mathbf{A S}}<\mathbf{2 , 5}$ & CA (Cukup Aktif/Sedang) \\
$\mathbf{2 , 5} \leq \overline{\mathbf{A S}}<\mathbf{3 , 5}$ & A (Aktif) \\
$\mathbf{3 , 5} \leq \overline{\mathbf{A S}} \leq \mathbf{4}$ & SA (Sangat Aktif) \\
\hline
\end{tabular}

Analisis data keefektifan perangkat pembelajaran terdiri dari analisis data aktivitas siswa dan analisis kemampuan HOTS siswa. Dalam menganalisis data aktivitas siswa, untuk menghitung banyak siswa yang memberi respons positif sesuai dengan aspek yang ditanyakan, menghitung persentase, dan menentukan kategori untuk respons positif siswa dengan cara mencocokkan hasil persentase dengan kriteria yang ditetapkan. Kriteria yang ditetapkan untuk menyatakan bahwa para siswa memiliki respons positif adalah minimal 50\% dari siswa memberi respons positif terhadap minimal $70 \%$ jumlah aspek yang ditanyakan.

Analisis kemampuan HOTS siswa dilakukan dengan teknik analisis data rata-rata nilai pretest dan posttest adalah dengan menggunakan rumus $N$ - 
gain ternormalisasi menurut Hake dalam Rosdianto \& Murdani (2017), pada persamaan berikut.

$$
\langle g\rangle=\frac{\left\langle S_{\text {post }}\right\rangle-\left\langle S_{\text {pre }}\right\rangle}{\left\langle S_{\text {max }}\right\rangle-\left\langle S_{\text {pre }}\right\rangle}
$$

Keterangan:

$\langle g\rangle=$ gain ternormalisasi

$\left\langle S_{\text {pre }}\right\rangle=$ Skor tes awal

$\left\langle S_{\text {post }}\right\rangle=$ Skor tes akhir

$\left\langle S_{\max }\right\rangle=$ Skor maksimum

Tabel 2. Kategori Tingkat N-gain

\begin{tabular}{cc}
\hline Gain $\langle\boldsymbol{g}\rangle$ & Kriteria \\
\hline$\langle\mathbf{g}\rangle>\mathbf{0 , 7}$ & Tinggi \\
$\mathbf{0 , 3} \leq\langle\mathbf{g}\rangle \leq \mathbf{0 , 7}$ & Sedang \\
$\langle\mathbf{g}\rangle<\mathbf{0 , 3}$ & Rendah \\
\hline
\end{tabular}

\section{HASIL PENELITIAN DAN PEMBAHASAN}

Hasil penelitian diuraikan dalam langkah-langkah pada setiap tahapan kegiatan penelitian. Tahapan pertama yaitu penelitian awal dan pengumpulan informasi. SMP Negeri 2 Bua sudah menggunakan kurikulum K13 pada tahun pelajaran 2018/2019 dan salah satu kompetensi dasar yang pada kurang tercapai adalah materi bangun ruang sisi datar. Materi geometri merupakan materi yang cukup sulit bagi siswa jika dilihat dari hasil survei awal siswa kelas VIII A dan hasil UNBK siswa kelas IX tahun pelajaran 2017/2018.

Tahapan kedua yaitu perencanaan (planning). Perencanaan yang dilakukan adalah mengunduh dan menginstal aplikasi geogebra, mengumpulkan materi-materi geometri yang sesuai dengan materi setiap pertemuan, membuat format RPP sesuai dengan permendikbud nomor 22 tahun 2016, membuat kerangka buku bacaan siswa dan membuat kerangka atau format Lembar Kerja Peserta Didik (LKPD).

Tahapan ketiga yaitu mengembangkan format awal produk. Produk yang dihasilkan dalam kegiatan pengembangan bahan ajar berupa Rencana Pelaksanaan Pembelajaran (RPP), Lembar Kerja Peseta Didik (LKPD), buku bacaan siswa, membuat evaluasi sebagai bahan tes, dan Instrumen penilaian. Instrumen-instrumen kevalidan, kepraktisan, dan keefektifan direalisasikan pada tahap ini. Lembar validasi yang digunakan yaitu: (1) lembar validasi perangkat pembelajaran (RPP, buku bacaan siswa, dan LKPD); (2) lembar 
observasi aktivitas siswa; (3) angket respons siswa; (4) lembar evaluasi kemampuan HOTS siswa; (5) lembar observasi keterlaksanaan pembelajaran; dan (6) format validasi untuk tiap instrumen yang disebutkan pada bagian (2), (3) dan (4). produk ini diberi nama prototipe-I.

Perangkat pembelajaran dan instrumen penelitian divalidasi terlebih dahulu sebelum diterapkan. Berikut rangkuman hasil penilaian para ahli terhadap perangkat pembelajaran yang meliputi rencana pelaksanaan pembelajaran, lembar kerja peserta didik, dan buku bacaan siswa.

Tabel 3. Rangkuman Hasil Validasi Perangkat Pembelajaran

\begin{tabular}{cccc}
\hline No. & Perangkat Pembelajaran & $\bar{X}$ & Ket. \\
\hline 1 & RPP & 3,6 & Sangat Valid \\
2 & LKPD & 3,6 & Sangat Valid \\
3 & Buku Bacaan Siswa & 3,7 & Sangat Valid \\
& Rata-Rata & 3,6 & Sangat Valid \\
\hline
\end{tabular}

Berdasarkan tabel 3, dapat disimpulkan bahwa perangkat pembelajaran yang telah divalidasi berada dalam kategori sangat valid, sehingga perangkat dapat digunakan. Secara umum, semua penilaian validator terhadap perangkat pembelajaran memberikan kesimpulan yang sama yaitu perangkat pembelajaran ini baik dan dapat digunakan tetapi masih perlu dilakukan revisi karena masih ada kesalahan dan kekurangan sebelum perangkat pembelajaran ini diujicobakan pada uji coba lapangan awal.

Rangkuman hasil penilaian para ahli terhadap instrumen penelitian yang meliputi soal pretest, soal posttest, lembar pengamatan keterlaksanaan pembelajaran, lembar pengamatan aktivitas siswa, dan angket respon siswa.

Tabel 4. Rangkuman Hasil Validasi Instrumen Penelitian

\begin{tabular}{clcc}
\hline No & \multicolumn{1}{c}{ Instrumen Penelitian } & $\bar{X}$ & Ket. \\
\hline 1 & Soal pretest & 3,5 & Sangat Valid \\
2 & Soal posttest & 3,6 & Sangat Valid \\
3 & Lembar Pengamatan Keterlaksanaan & 3,2 & Valid \\
& Pembelajaran & 3,3 & Valid \\
4 & Lembar Pengamatan Aktivitas Siswa & 3,4 & Valid \\
5 & Angket Respons Siswa & 3,4 & Valid \\
\hline
\end{tabular}


Berdasarkan tabel 4, dapat disimpulkan bahwa instrumen penelitian yang telah divalidasi berada dalam kategori valid, sehingga instrumen penelitian dapat digunakan. Sementara itu, secara umum semua penilaian validator terhadap instrumen penelitian memberikan kesimpulan yang sama yaitu instrumen penelitian ini baik dan dapat digunakan dengan sedikit revisi.

Berikut beberapa tampilan dari perangkat yang dikembangkan.

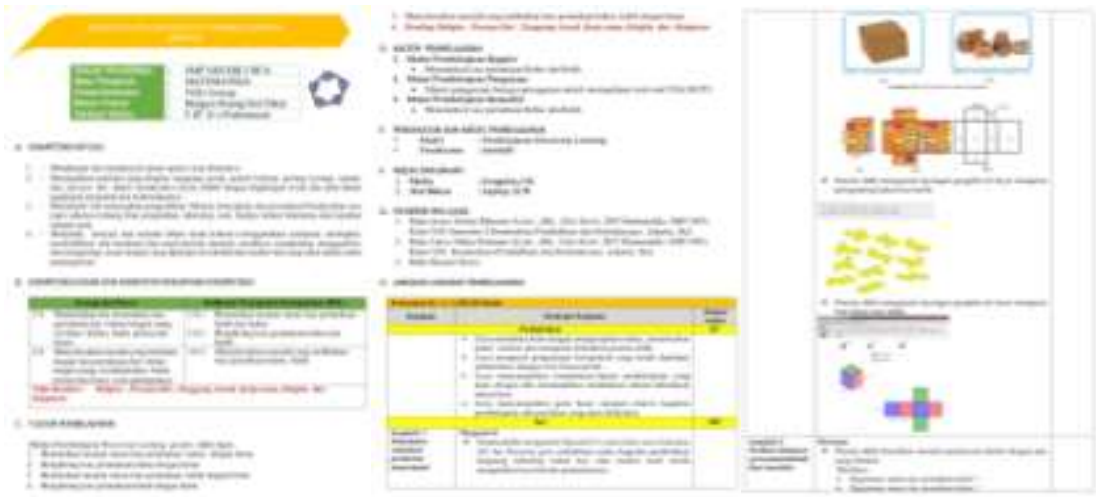

Gambar 1. Tampilan dari RPP yang Dikembangkan
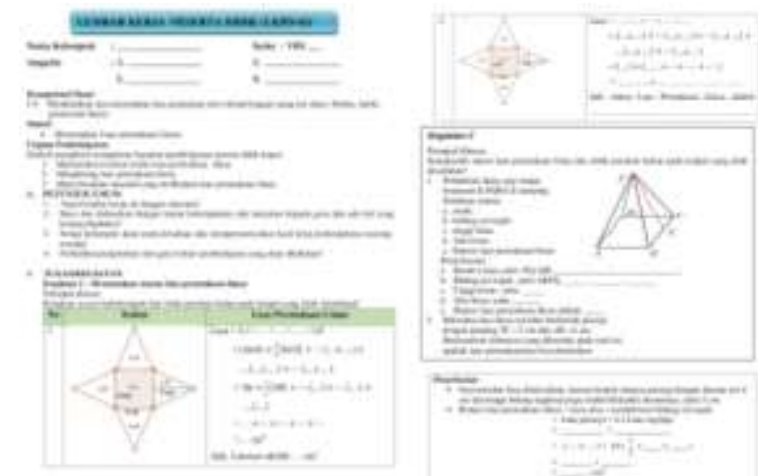

Gambar 2. Tampilan dari LKPD yang Dikembangkan
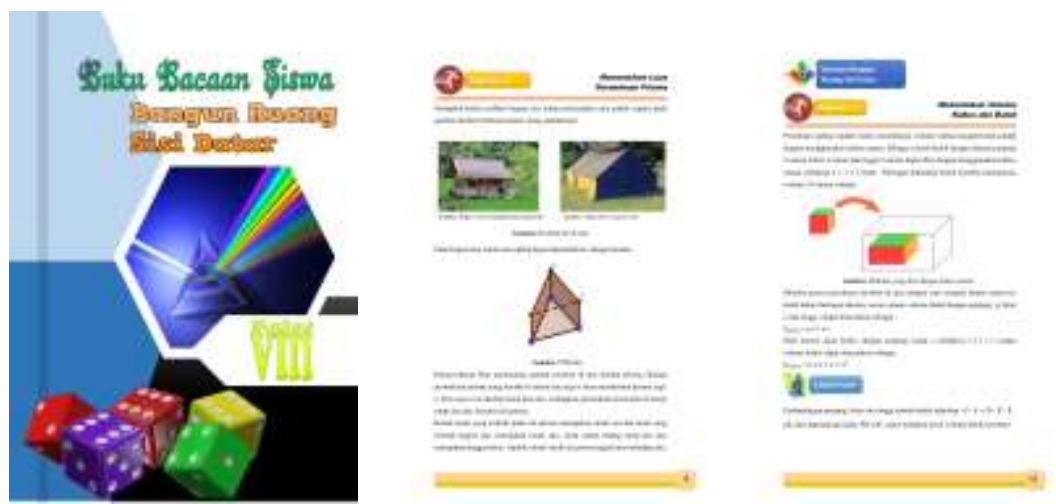

Gambar 3. Tampilan dari Buku Bacaan Siswa yang Dikembangkan 
Tahapan keempat yaitu uji lapangan awal atau uji coba terbatas. Uji coba perangkat pembelajaran berbasis geogebra untuk menilai kepraktisan. Perangkat pembelajaran berbasis geogebra dikatakan praktis jika memenuhi 2 syarat, yaitu: (1) keterlaksanaan pembelajaran berada minimal pada kategori terlaksana sebagian dan (2) aktivitas siswa berada minimal pada kategori aktif. Berikut ini adalah hasil uji kepraktisan perangkat pembelajaran berbasis geogebra pada uji lapangan awal kelas VIII A.

Tabel 5. Hasil Uji Keprakrisan Perangkat Pembelajaran Berbasis Geogebra pada Uji Lapangan Awal Kelas VIII A

\begin{tabular}{cccc}
\hline No & Aspek Penilaian & $\overline{\boldsymbol{X}}$ & Keterangan \\
\hline 1 & Keterlaksanaan & 1,64 & Terlaksana Seluruhnya \\
2 & Pembelajaran & 3,67 & Sangat Aktif \\
\hline
\end{tabular}

Rata-rata keseluruhan aspek dari keterlaksanaan pembelajaran $\bar{X}=1,64$ berada dalam kategori "terlaksana seluruhnya" dan rata-rata keseluruhan aspek dari aktivitas siswa $\bar{X}=3,67$ berada dalam kategori "sangat aktif", maka dapat disimpulkan bahwa keterlaksanaan pembelajaran dan aktivitas siswa dengan menggunakan perangkat pembelajaran berbasis geogebra ini telah memenuhi kriteria kepraktisan. Uji coba perangkat pembelajaran berbasis geogebra untuk menilai keefektifan

Berdasarkan hasil analisis respons siswa terhadap pembelajaran di kelas, LKPD dan buku bacaan siswa pada uji lapangan awal, ada 4,80\% siswa memberi respons negatif dan 95,20\% siswa memberi respons positif. Dengan demikian menurut kriteria yang digunakan, pada uji lapangan awal siswa telah merespons positif terhadap perangkat dan proses pembelajaran.

Untuk mengetahui peningkatan kemampuan higher order thinking skills dalam pembelajaran berbasis geogebra pada uji lapangan awal, maka dilakukan dua kali tes yaitu pretest yang diberikan sebelum pembelajaran dan posttest diberikan sesudah pembelajaran. Distribusi frekuensi $g$ factor dideskripsikan pada tabel berikut. 
Tabel 6. Distribusi Frekuensi dan Persentase G Factor Uji Lapangan Awal Kelas VIII A

\begin{tabular}{ccccc}
\hline No & Rentang Nilai & Kategori & Frekuensi & Persentase \\
\hline 1 & $\langle\mathrm{~g}\rangle>0,7$ & Tinggi & 4 & 13,33 \\
2 & $0,3 \leq\langle\mathrm{g}\rangle \leq 0,7$ & Sedang & 24 & 80,00 \\
3 & $\langle\mathrm{~g}\rangle<0,3$ & Rendah & 2 & 6,67 \\
\hline
\end{tabular}

Berdasarkan tabel 6, tampak bahwa persentase siswa yang gain faktornya $(g)$ dalam kategori rendah adalah 13,33\%, dalam kategori sedang adalah $80,00 \%$, dan kategori tinggi adalah 6,67\%. Rerata $g$ factor adalah 0,53. Dilihat dari kategori kualitas rerata $g$ factor ini termasuk dalam kategori sedang. Jadi, penerapan pembelajaran berbasis geogebra meningkatkan kemampuan HOTS siswa kelas VIII A dalam kategori sedang.

Tahapan kelima adalah revisi produk utama. Berdasarkan hasil uji lapangan awal sebelumnya kemudian dilaksanakan revisi produk. Revisi ini dilakukan berdasarkan pertimbangan dari observer dan dosen yang telah melakukan kunjungan saat peneliti melakukan proses pembelajaran pada uji lapangan awal. Berikut beberapa revisi yang dilakukan dapat dilihat pada tabel berikut.

Tabel 7. Revisi Perangkat Pembelajaran Berdasarkan Saran Dosen Pembimbing dan Observer

\begin{tabular}{ll}
\hline $\begin{array}{c}\text { Perangkat } \\
\text { Pembelajaran }\end{array}$ & \multicolumn{1}{c}{ Saran Perbaikan } \\
\hline RPP & $\begin{array}{l}\text { Pada proses pembelajaran setiap kelompok mewakili } \\
\text { kelompoknya untuk tampil menggunakan aplikasi geogebra } \\
\text { di depan kelas. Pertemuan berikutnya memberikan } \\
\text { kesempatan kepada siswa yang belum tampil }\end{array}$ \\
& $\begin{array}{l}\text { LKPD 1 Soal Nomor 5 direvisi soalnya supaya } \\
\text { menghasilkan soal yang lebih HOTS dari sebelumnya }\end{array}$ \\
LKPD & $\begin{array}{l}\text { LKPD 4 pada kegiatan 2 soal Nomor 2, banyak kubus } \\
\text { satuan awalnya 27 diubah menjadi 24 satuan }\end{array}$ \\
Buku Bacaan & $\begin{array}{l}\text { Proses pembelajaran sebaiknya setiap siswa mendapatkan } \\
\text { satu buku. }\end{array}$ \\
\hline
\end{tabular}

Tahapan keenam adalah uji lapangan utama yang terdiri dari uji coba perangkat pembelajaran berbasis geogebra untuk menilai kepraktisan dan uji coba perangkat pembelajaran berbasis geogebra untuk menilai keefektifan. Dalam uji coba perangkat pembelajaran berbasis geogebra untuk menilai 
kepraktisan, perangkat pembelajaran berbasis geogebra dikatakan praktis jika memenuhi 2 syarat, yaitu: (1) keterlaksanaan pembelajaran berada minimal pada kategori terlaksana sebagian dan (2) aktivitas siswa berada minimal pada kategori aktif. Berikut ini adalah hasil uji kepraktisan perangkat pembelajaran berbasis geogebra pada uji lapangan awal kelas VIII A.

Tabel 8. Hasil Uji Keprakrisan Perangkat Pembelajaran Berbasis Geogebra pada Uji Lapangan Awal Kelas VIII A

\begin{tabular}{cccc}
\hline No & Aspek Penilaian & $\overline{\boldsymbol{X}}$ & Keterangan \\
\hline 1 & Keterlaksanaan & 1,76 & Terlaksana Seluruhnya \\
2 & Pembelajaran & 3,85 & Sangat Aktif \\
\hline
\end{tabular}

Rata-rata keseluruhan aspek dari keterlaksanaan pembelajaran $\bar{X}=1,76$ berada dalam kategori "terlaksana seluruhnya" dan rata-rata keseluruhan aspek dari aktivitas siswa $\bar{X}=3,85$ berada dalam kategori "sangat aktif", maka dapat disimpulkan bahwa keterlaksanaan pembelajaran dan aktivitas siswa dengan menggunakan perangkat pembelajaran berbasis geogebra ini telah memenuhi kriteria kepraktisan.

Uji coba perangkat pembelajaran berbasis geogebra untuk menilai keefektifan dilakukan berdasarkan hasil analisis respons siswa terhadap pembelajaran di kelas, LKPD, dan buku bacaan siswa pada uji lapangan utama. Diperoleh bahwa ada 9,31\% siswa memberi respon negatif dan 90,69\% siswa memberi respon positif. Menurut kriteria yang digunakan, pada uji lapangan utama siswa telah merespons positif terhadap perangkat dan proses pembelajaran.

Peningkatan kemampuan HOTS dalam pembelajaran berbasis geogebra pada uji lapangan utama diukur dengan melakukan dua kali tes yaitu pretest yang diberikan sebelum pembelajaran dan posttest diberikan sesudah pembelajaran. Distribusi frekuensi $g$ factor dideskripsikan pada tabel berikut:

Tabel 9.Distribusi Frekuensi dan Persentase G Factor Uji Lapangan Utama Kelas VIII E dan VIII F

\begin{tabular}{ccccc}
\hline No & Rentang Nilai & Kategori & Frekuensi & Persentase \\
\hline 1 & $\langle\mathrm{~g}\rangle>0,7$ & Tinggi & 3 & 4,92 \\
2 & $0,3 \leq\langle\mathrm{g}\rangle \leq 0,7$ & Sedang & 52 & 85,24 \\
3 & $\langle\mathrm{~g}\rangle<0,3$ & Rendah & 6 & 9,84 \\
\hline
\end{tabular}


Berdasarkan tabel 9, tampak bahwa persentase siswa yang gain faktornya $(g)$ dalam kategori rendah adalah 4,92\%, dalam kategori sedang adalah $85,25 \%$, dan kategori tinggi adalah 9,84\%. Rerata $g$ factor adalah 0,45. Dilihat dari kategori kualitas rerata $g$ factor ini termasuk dalam kategori sedang. Jadi, penerapan pembelajaran berbasis geogebra dapat meningkatkan kemampuan HOTS siswa kelas VIII E dan VIII F dalam kategori sedang.

Tahapan terakhir yaitu diseminasi dan implementasi. Produk yang telah dibuat kemudian disebarluaskan kepada pihak yang terkait dan selanjutnya siap untuk diimplementasikan. Produk ini disebar melalui Flash disk, DVD bahkan diunggah di group MGMP Matematika zigma Kab. Luwu agar para guru dapat mengunduh dan menggunakan perangkat pembelajaran ini secara gratis.

Hasil yang diperoleh dari penelitian ini adalah perangkat pembelajaran yang berbasis media aplikasi geogebra pada materi geometri (bangun ruang sisi datar) yang dikembangkan memenuhi kriteria valid, tetapi dengan revisi kecil. Dapat disimpulkan bahwa seluruh perangkat yang terdiri dari rencana pembelajaran, lembar kerja siswa, buku bacaan siswa, tes hasil belajar, dan instrumen penelitian layak untuk diujicobakan di lapangan.

Secara umum untuk kriteria kepraktisan pada uji lapangan awal telah terpenuhi, yaitu keterlaksanaan pembelajaran berada kategori "terlaksana seluruhnya" dan aktivitas siswa berada kategori "sangat aktif". Namun jika ditelusuri lebih jauh, untuk beberapa komponen, yang perlu ditingkatkan pelaksanaannya pada uji lapangan utama. Untuk kriteria kepraktisan pada uji lapangan utama telah terpenuhi, yaitu keterlaksanaan berada pada kategori "terlaksana seluruhnya" dan aktivitas siswa berada pada kategori "sangat aktif". Hal ini sejalan dengan Nieveen dalam Kumalasani (2018) yang menyatakan kepraktisan dapat dilihat dari pengguna produk seperti guru, siswa dan ahli lainnya yang tidak mengalami kesulitan dalam menggunakan produk. Selain itu produk yang dikembangkan memiliki keterlaksanaan yang sesuai.

Untuk kriteria keefektifan, pada uji lapangan awal perangkat pembelajaran yang dikembangkan telah memenuhi kriteria keefektifan, yaitu respons siswa cenderung positif dan peningkatan kemampuan HOTS siswa berada pada kategori sedang. Namun, masih ada berapa komponen yang memerlukan perbaikan. Pada uji lapangan utama, perangkat pembelajaran yang dikembangkan telah memenuhi kriteria keefektifan, yaitu respons siswa cenderung positif dan peningkatan kemampuan HOTS siswa berada pada 
kategori sedang. Peningkatan HOTS siswa pada uji lapangan awal dan utama karena perangkat pembelajaran yang dikembangkan memudahkan guru dan siswa memahami objek-objek geometri yang abstrak dan saling berkaitan. Hal tersebut sejalan dengan penelitian Nur (2017) bahwa bahan ajar berbantuan geogebra yang dikembangkan sangat membantu siswa dan guru pada proses pembelajarannya.

\section{SIMPULAN}

Pengembangan perangkat pembelajaran berbasis media aplikasi geogebra pada materi geometri memenuhi kriteria kevalidan, kepraktisan dan keefektifan. Berdasarkan indikator kevalidan yaitu validasi RPP, LKPD, buku bacaan siswa diperoleh rerata total $\bar{X}=3,6$, maka perangkat pembelajaran ini telah memenuhi kriteria kevalidan dan berada dalam kategori "Sangat Valid". Berdasarkan indikator kepraktisan yaitu keterlaksanaan pembelajaran dan aktivitas siswa diperoleh hasil sebagai berikut: (1) keterlaksanaan pembelajaran mendapatkan rerata skor 1,64 dengan kategori terlaksana seluruhnya untuk uji coba lapangan awal dan 1,76 dengan kategori terlaksana seluruhnya untuk uji coba lapangan utama dan (2) aktivitas siswa mendapatkan rerata skor 3,67 yang berarti kategori sangat aktif untuk uji coba lapangan awal dan 3,85 yang berarti kategori sangat aktif untuk uji coba lapangan utama, dengan perolehan tersebut perangkat pembelajaran dinyatakan praktis. Berdasarkan indikator keefektifan yaitu respons siswa dan kemampuan HOTS siswa diperoleh hasil sebagai berikut: (1) respons siswa, ada $4,80 \%$ siswa memberi respons negatif dan 95,20\% siswa memberi respons positif untuk uji coba lapangan awal dan ada 9,31\% siswa memberi respons negatif dan 90,69\% siswa memberi respons positif untuk uji coba lapangan utama dan (2) kemampuan HOTS siswa, rerata $g$ factor adalah 0,53 dalam kategori sedang untuk uji coba lapangan awal dan 0,45 juga dalam kategori sedang untuk uji coba lapangan utama, dengan perolehan tersebut perangkat pembelajaran dinyatakan efektif.

\section{UCAPAN TERIMA KASIH}

Tim peneliti menyampaikan terima kasih kepada Direktorat Riset dan Pengabdian Masyarakat Kementerian Riset, Teknologi, dan Pendidikan Tinggi yang telah memberikan hibah penelitian pada tahun 2019. 


\section{DAFTAR PUSTAKA}

Abdussakir. (2013). Penggunaan komputer untuk pembelajaran matematika. Madrasah, 5(1), 117-133. Retrieved from https:/ / www.researchgate.net/ publication/304205739_penggunaan_komputer_untuk_pembelajaran_ matematika.

Arsyad, N. (2016). Model pembelajaran menumbuh kembangkan kemampuan metakognitif. Makassar: Pustaka Refleksi.

Azizah, F. R., Sujadi, I., \& Chrisnawati, H. K. (2018). Penerapan problem based learning pada materi luas permukaan serta volume prisma dan limas ditinjau dari kemandirian belajar siswa kelas VIII SMP Negeri 2 Banyudono. Jurnal Pendidikan Matematika dan Matematika (JPMM) Solusi, 2(4), 298-306. Retrieved from https://jurnal.uns.ac.id/JMMS/article/vi ew/ 22754 .

Dinni, H. N. (2018). HOTS (High Order Thinking Skills) dan kaitannya dengan kemampuan literasi matematika. In PRISMA, Prosiding Seminar Nasional Matematika (Vol. 1, pp. 170-176). Semarang. Retrieved from https://jour nal.unnes.ac.id/sju/index.php/prisma/article/view/19597.

Kumalasani, M. P. (2018). Kepraktisan penggunaan multimedia interaktif pada pembelajaran tematik kelas IV SD. Jurnal Bidang Pendidikan Dasar, 2(1A), 1-11. Retrieved from http:/ / ejournal.unikama.ac.id/index.php/JBPD/ article/view/2345

Ma'rufi, Pasandaran, R. F., \& Yogi, A. (2018). Pemahaman konsep geometri mahasiswa berdasarkan gaya kognitif mahasiswa. Proximal: Jurnal Penelitian Matematika dan Pendidikan Matematika, 1(2), 56-67. Retrieved fromhttp://www.journal.uncp.ac.id/index.php/proximal/article/dow nload/1053/919.

Mahmudi, A. (2011). Pemanfaatan geogebra dalam pembelajaran matematika. In Prosiding Seminar Nasional Matematika dan Pendidikan Matematika Universitas Negeri Yogyakarta (pp. 1-10). Yogyakarta. Retrieved from http://webcache.googleusercontent.com/search?q=cache:eELRg4E5wJ EJ:staffnew.uny.ac.id/upload/132240454/penelitian/Makalah\%2B17\% 2BSemnas\%2BLPM\%2BUNY\%2B2011\%2B_Pemanfaatan\%2BGeoGebra $\%$ 2Bdalam\%2BPembelajaran\%2BMatematika_pdf+\&cd=2\&hl=en\&ct $=\mathrm{C}$ lnk\&gl=id\&client=firefox-b-d.

Nur'aini, I. L., Harahap, E., Badruzzaman, F. H., \& Darmawan, D. (2017). Pembelajaran matematika geometri secara realistis dengan geogebra. Matematika: Jurnal Teori dan Terapan Matematika, 6(2), 1-6. Retrieved from https:/ / ejournal.unisba.ac.id/index.php/matematika/article/vie $\mathrm{w} / 3900$.

Nur, F. (2017). Pengembangan bahan ajar matematika kelas VII SMP berdasarkan model pembelajaran Kolb-Knisley berbantuan geogebra sebagai upaya meningkatkan higher-order thinking skill dan apresiasi 
siswa terhadap matematika. MaPan : Jurnal Matematika dan Pembelajaran, 5(1), 96-109. Retrieved from http://journal.uin-alauddin.ac.id/index.p $\mathrm{hp} /$ Mapan/article/view/2853.

Nur, I. M. (2016). Pemanfaatan program geogebra dalam pembelajaran matematika. Delta-Pi: Jurnal Matematika dan Pendidikan Matematika, 6(1), 10-19. Retrieved from http:/ / www.ejournal.unkhair.ac.id/index.php/ deltapi/article/viewFile/236/188.

Rosdianto, H., \& Murdani, E. (2017). The implementation of POE (Predict Observe Explain) model to improve student's concept understanding on Newton's law. Jurnal Pendidikan Fisika Unimed, 6(1), 55-57. Retrieved from https://www.neliti.com/publications/120192/the-implementatio n-of-poe-predict-observe-explain-model-to-improve-students-conc.

Sari, F. K., Farida, F., \& Syazali, M. (2016). Pengembangan media pembelajaran (modal) berbantuan geogebra pokok bahasan turunan. Al-Jabar: Jumal Pendidikan Matematika, 7(2), 135-152. Retrieved from http://ejournal.radenintan.ac.id/index.php/al-jabar/article/view/24.

Suryapuspitarini, B. K., Wardono, W., \& Kartono, K. (2018). Analisis soal-soal matematika tipe Higher Order Thinking Skill (HOTS) pada kurikulum 2013 untuk mendukung kemampuan literasi siswa. In PRISMA, Prosiding Seminar Nasional Matematika (Vol. 1, pp. 876-884). Semarang. Retrieved from https://journal.unnes.ac.id/sju/index.php/prisma/arti cle/view/20393. 